\title{
Military Operation as a Response to Terrorism: A Case Study of Malakand Division Pakistan
}

\author{
Dr. Manzoor Khan Afridi \\ Head of Department of Politics and International Relations, International Islamic University Islamabad-Pakistan \\ manzoor_s01@yahoo.com, manzoor.afridi@iiu.edu.pk \\ Musab Yousufi \\ M.Phil Scholar, International Islamic University Islamabad-Pakistan \\ musab_yousufi@live.com \\ Musa Khan \\ M.Phil Scholar, International Islamic University Islamabad-Pakistan \\ musakhan_85@yahoo.com
}

\section{Doi:10.5901/mjss.2014.v5n20p2000}

\section{Abstract}

After 9/11 attacks Pakistan joined the anti-terrorists block like United States, and gave much support to them against insurgent and terrorist groups in Afghanistan. Therefore Pakistan is also facing more difficulties and complexities, like death and destruction because of frontline ally. The consequences of those policies also brought terrorism in Pakistan, to counter that terrorism Pakistan use hard powers and military operations for its elimination. Terrorism and military operation has a strong effect on the behavior of people and plays destructive role in the disturbance of people's lives and government activities in the region. In Malakand division where the literacy is low, people have strong belief on religion, having strict cultural norms therefore it was easy for insurgent groups that they misguide the innocent people with misinterpretation of religion. According to research government negligence was responsible for terrorism and military operations in the region. But government did not use and tried all other measures particularly diplomatic means or peace deal, before resorting to operation. This all lacks open room for insurgent groups to have footing there in Malakand division.

Keywords: Economic Dislocation, Military Operation, Strict Culture Norms, Terrorism, Insurgent

\section{Introduction}

Military operation is a planned and controlled movement or operation by the armed forces for training purposes and in war. Military operation is the military actions of a state in response to a developing situation. These actions are designed as a military plan to resolve any issue and control the situation in the state's interests. Operations may be of combat or non-combat types (Glantz, 1991). The military operation have code name for security and also a general name for common usage i.e. Pakistan military operation Rah-e-rast or Rah-e-nijat.

Similar to and reflecting this structure and framework for operations are planned elements within the armed forces which prepare for and conduct operations at various stages of war. Though there is a general relationship between the size of units, the region inside which they operate, and the scope of mission they achieve, the relationship is not absolute. Actually, it is eventually the mission that a unit performs and determines the level of war inside which it operates (Glantz, 1991).

\subsection{Military Operations in Pakistan}

Science beginning Pakistan is a security state. From 2001, the Pakistan Army has been concerned to ensuring state internal security and stability through tackling terrorism insurgency and militancy in the Federally Administered Tribal Areas (FATA) and the Provincially Administered Tribal Areas (PATA). FATA include seven agencies, i.e. Bajaur, Mohmand, Orakzai, Khyber, Kurram, North Waziristan, and South Waziristan. While PATA of Khyber Pakhtun-Khwa 
(KPK) includes the districts of Buner, Lower Dir, Shangla, Swat and Upper Dir.

Insurgency terrorism and militancy is one of the alarming and disturbing challenges to the country security, it also disturb the economic prosperity and socio-political stability, of Pakistan. The Pak-Army has resolved to carry changes in its track, direction, motivation, thinking and policy for the last many years in order to face these challenges. In this view, for counter terrorism the Pak-Army has launched many operations but some five major and some minor operations against the militants, insurgent groups and terrorists.

The insurgent group of Tehrik-e-Taliban Pakistan (TTP), Tehrik Nifaz-e-Shariat-e-Muhammadi (TNSM), and the fundamentalist organizations to use religious background and other foreign-linked fundamentalist are matters of severe concern to Pakistan. The Pak-Army has used heavy ground and air weapons during the operations. That has also resulted in enormous and huge collateral damage. The killing of guiltless, blameless and innocent people, including women and children, the destruction of educational institutions as a result of these operations, together with the casualties cause by suicide attacks have wide consequence and implications on internal security. The domestic sociopolitical situation and the economic conditions of FATA and PATA have been rendered fragile as a consequence of all this. The ultimate goal of such operations is to force the terrorists and insurgent groups out of their strongholds and to destroy their power and military infrastructure in order to stop them from launching future attacks and terrorist activities. The goals of military operations were also to re-establish the writ and hold of the government.

Pakistan army conducted the military operations, with the support of the police and the frontier constabulary (FC) in the different parts of the country, mainly in PATA and FATA. The military operations have many consequences to examine like the political, economic and social implications of these operations on Pakistan.

\subsubsection{Military operations by Pakistan Army}

Pakistan army with the help of other forces conducted major five operations since 2001:

From 2001 to 2002- Operation Enduring Freedom,

From 2002 to 2006- Operation Al Mizan,

In 2008- Operation Zalzala,

From 2007 to 2009- Conducted two operations Operations Sher Dil, Rah-e-Haq, and Rah-e-Rast and,

From 2009 to 2010- Operation Rah-e-Nijat.

\section{What is terrorism?}

Terrorism is a complex term with a long history and different meanings, depending on the context and who uses it (About.com, 2013). According to Walter Liqueur terrorism constitutes the illegitimate use of force to achieve a political objective when innocent people are targeted (Laqueur, 2013). Brian Jenkins says Terrorism is the use or threatened use of force designed to bring about political change (Jenkins, 2013). Terrorism can be defined as the use of violence by nonstate actors against civilians in orders to achieve a political goal (O'Neil, 2007).

Terrorism is the methodical and systematic use of terror, particularly as a means of compulsion or force. In the world community, though terrorism has no commonly agreed, legally binding or criminal law definition. General definitions of terrorism refer only to those violent and brutal acts which are proposed to create fear (terror), are place for a religious, political or, ideological objective, and deliberately target or ignore the safety of non-combatants (civilians). The acts of unlawful violence and war also called terrorism.

\subsection{Terrorism in Pakistan}

Terrorism in Pakistan has become a major and highly destructive phenomenon in recent years. The annual death toll from terrorist attacks has risen from 164 in 2003 to 3318 in 2009, with a total of 35,000 Pakistanis killed as of 2010 (Hassan, 2013).

After 9/11 America attacked on Afghanistan and Pakistan was front ally of US. The government of Pakistan gave full support to US and US used the Pakistan territory for its own fight. Majority people of Pakistan were unhappy on the decision of home country. Especially the religious parties and groups started strike against the decision of the government. Majority of people, religious groups, organization of human rights etc tried to record their protests on the legal way but some emotional and misguided people tried to challenge the writ of the state. Some religious fighters like Mulana Sufi Muhammad, Mulana Fazluullah, Bait ullah Mehsood etc misguided the innocent people of the FATA and PATA( Rahman, 2011). 


\section{Military Operation and Terrorism in Malakand Division}

Military Operation was launched against religious extremists in parts of Malakand Division which included Swat, Buner and Dir Lower. Though the operation was started in order to establish writ of the Government and provide safe, harmonious and democratic life to people of the area but at the same time it caused plenty of troubles such the shattered economy, increased unemployment, poor health and education, and of course the Internally Displaced Persons (IDPs) and their relevant troubles.

Pakistan army launched a huge offensive against insurgent groups, militants and terrorism in Malakand region of KPK in the very last week of April 2009. The operation was selected as a last option after the failure of two peace accord of the provincial government, first agreement with the local Taliban group, led by Mullah Fazlullah, and second agreement with past Taliban group TNSM headed by Sufi Muhammad. Taliban had rejected, in infringement of the agreement, to put down their weapons even after the circulation of the Nizam-e-Adl Regulation in the restive region. Taliban attacks on Pakistan army and other security forces including, Frontier Corps (FC) and police did not stop either. Before the launch of the military operation and while the peace agreement was still unbroken, militants and insurgent groups carried out 18 terrorist attacks in Swat, Dir and Buner districts of Malakand division region in the month of April alone. Eight of these attacks targeted Pak-army and security forces, including the police. That was a clear sign that the militants had no respect for the peace accord and wanted to follow their own agenda. Certainly it was Taliban's advance into neighboring areas of Swat, mainly Buner and Shangla, which forced the government to launch an operation.

The Pak-army and security operation in Malakand division is the 15th major military operation against militants and Taliban in KPK and FATA of Pakistan. Almost all previous operations had finally ended with the government attainment a peace agreement or ceasefire with Taliban. After each agreement, the government declared its victory. Taliban, nevertheless, used these agreements strategically to their advantage. These deals had not only merged their control in certain areas but also helped them make new recruitments and vital for making further advances (Rana, 2009).

\subsection{Negligence of Government}

In 1989, Maulana Sufi Muhammad laid the foundation of Tehreek-i-Nifaz-i-Shariat-i-Muhammadi on 28 June, 1989 in Maidan, Lower Dir. Sufi Muhammad, had limited activities of the TNSM in the Malakand Division and comprising the districts of Upper Dir, Lower Dir, Chitral, Malakand, Swat, Buner and Shangla, the Kohistan district of Hazara Division and Bajaur Agency. After fast support for the movement, he demanded the enforcement of the Shariah in these areas (Khan, 2010).

It is clear that the people of Malakand division have a historical tradition and obedience to religious authority based on their past. Thus, when Sufi Mohammad in 1994 began his TNSM movement for the introduction of Shariah they gave him support. They also followed him into Afghanistan in Nov 2001 when he asked them to Jihad against the US and NATO forces (Khan, 2010).

The political parties were interested in breaking the hold of the Jamat e Islami in the region and they wanted to use Sufi Mohammad as a weapon for this purpose (Aziz, 2010).

\subsection{Emergence of TNSM}

After the combination of Swat, Dir and Chitral states, in 1976 the PATA Regulations were implemented. Under these regulations the Qazi courts were abolished and powers were handed over to the Tehsildar who used to organize jirgah of Khans to decide legal cases. Cases were kept pending for years causing hardship to the people. The appeal against the jirgah decisions lay with the Deputy Commissioner. Under the PATA Regulations anyone could be arrested or detained without any reason (Aziz, 2010).

In 1991, he camped at Temergarah (now district headquarter of Lower Dir), along with hundreds of his supporters demanding the enforcement of Shariat in Malakand. He then called off his demonstration when Chief Minister Mir Afzal Khan's government assured him that his demands would be fulfilled (Aziz, 2010).

On Feb 12, 1994 the Supreme Court of Pakistan made a land mark decision ordering the government of KP that Malakand Division should not be governed under special provisions since these were discriminatory and violative of the Fundamental Rights provided under the Constitution (Ali, 2010).

The political parties were interested in breaking the hold of the Jamat e Islami in the region and they wanted to use Sufi Mohammad as a weapon for this purpose (Aziz, 2010).

With this decision of the Supreme Court Maulana Sufi Muhammad also gained confidence and financial support 
from these local Khans, Maliks and the executive authorities. In May, 1994 the Chief of the TNSM, Sufi Muhammad called off his week long protest campaign against the government. In November 1994, followers of Sufi Muhammad, launched an armed campaign for their demand and took control of many government installations in Swat District. Sufi Muhammad campaign forced the PPP-led government to propagate the Nifaz-e-Nizam-e-Shariah Regulation 1994 in the Provincially Administered Tribal Areas (Ali, 2010).

Not satisfied with the legislation, Sufi Muhammad continued to hold demonstrations. Subsequently, another Regulation called the "Shari-Nizam-e-Adal Regulation, 1999was promulgated. After 9/11, when American President ordered attack on Afghanistan to fall over Taliban government, Sufi Muhammad again motivated to support the Afghan Taliban in the war against the US (Ali, 2010).

Sufi Muhammad was then sentenced to three years imprisonment. In January 12, 2002 President Pervez Musharraf banned the TNSM. Though legally the TNSM was banned, but still it remains active in Malakand division, district of Kohistan and Bajaur Agency. In the absence of Sufi Muhammad, Maulana Abdul Ghafoor led the TNSM in Dir and Bajaur (Khan, 2010).

Sufi Muhammad remained in jail but Fazalullah was released after seventeen months. After his release, he opened unauthorized FM radio channel in his native village Mamdheri (only three kilometre away from Saidu Sharif District Headquarters of Swat and Divisional Headquarter of Malakand Division) to preach Islam. He was supported by the TNSM members in the beginning. Fazlullah in the beginning motivated people through polite speeches. Every night on 8 p.m. he started his (dars) speeches. Up to 2005, he was preaching peacefully (Khan, 2010).

After 9/11 attacks when USA intervened into Afghanistan, the Governor of NWFP Iftikhar Hussain Shah ordered the administration not to stop TNSM members and Sufi Muhammad from access into Afghanistan and provide them possible help. Political parties particularly, PPPP, PML (N), JI, JUI (F),MMA, PML (Q), ANP were equally responsible for the weakening Malakand situation. They all supported TNSM due to its growing political popularity in Malakand. Our agencies were more responsible for encouraging TNSM and Taliban in Malakand division and to create a better environment for them in Swat. The people of Swat were motivated by agencies towards TNSM. It is also very interesting to note that every year Maulana Sufi Muhammad started his demonstration and demands in April and May (Ali, 2010).

\section{Military Response to Terrorism in Malakand Division}

This will discuss about the military operation in Malakand division i.e. operation Rah-e-Haq and military operation Rah-eRast which was held in the Malakand region. The military operation era will discuss about the two main operations was conducted by government in Malakand division. The first military operation in 2007 was operation Rah-e-Haq and second is operation Rah-e-Rast in 2009.

\subsection{Operation Rah-e-Haq}

Despite the Swat Taliban's increasing militancy in the valley including the razing of CD shops, forcing women to stay at home. The ruling coalition of religious parties (MMA 2002-2008) in the KPK government, as well as the Pakistani central government, turned a blind eye to Swat in late 2006 and early 2007 (Khattak, 2010).

Operation Rah-e-Haq contains three phases; operation was begun on October 24, 2007 and involved the Pakistan Army and Taliban-led forces in a fight for control of the Swat district of Malakand division. Between October 25 and November 7, 2007 the militants quickly seized control of the region.

\subsubsection{First phase}

The Pakistani army launched the first phase of the Operation Rah-e-Haq, (Just Path), in early November 2007. Fighting between Pakistani forces and the Taliban continued throughout November, with the army employing heavy artillery shelling. The militants vacated almost all of the government buildings, police stations, and other public places they had occupied including those in Mam Dheri, the headquarters of Fazlullah and by the end of December they had move back to the mountains (Khattak, 2010).

\subsubsection{Second Phase}

Violent clashes were reported in Kabal, Matta, Khwazakhela, Bara Bandai, Kooza Bandai, and other main towns in Swat. But in late June the militants blew up, and accelerated their targeted killings and attacks on security forces. In July 2008, 
the second phase of operation Rah-e-Haq was took place (Fair et al, 2010) in the northern parts of the Swat valley and later spread to southern areas(Renno, 2010). A few prominent Taliban leaders, including Tor Mulla and Ali Bakht, were killed during the second phase (Khattak, 2010).

\subsubsection{Third phase}

The third and final phase began in January 2009, and the army imposed shoot-on-sight "curfews" in Swat major cities. Militants responded by destroying girls schools and attacking security forces. The government did peace deal with militants. The Malakand Accord or peace deal, signed in February 2009, institutionalized sharia law in the Malakand region. Militants failed to uphold their end of the deal by attacking government security forces, destroying schools, and setting up checkpoints and training camps (Renno, 2010).

By late April 2009, however, militants had begun to occupy shops and government buildings in Mingora, the largest city in Swat, and to move into parts of Swat and neighboring districts of Malakand division (Fair et al, 2010). In May 2009, the Pakistani military launched Operation Rah-e-Rast to clear out TTP militants in Swat District (Renno, 2010).

\section{Operation Rah-e-Rast}

After failing to influence the Taliban to vacate Buner, Dir, and Swat, where the militants had combine control in the first several months of 2009; the Pakistani army began another full-fledged series of military operations in late April. Local residents were asked earlier to vacate their areas, and between May and mid-July, nearly 2.5 million people arrived in Peshawar, Mardan, Swabi, Charsadda, Nowshera, and other Pakistani cities to live in camps, with relatives, or in rented houses (Khattak, 2010).

With support from the parliament, political parties the Pakistan army launched the Operation Rah-e-Rast to clean up the Malakand Division from terrorists and militants, started in early May 2009. The international community has also made full support to out terrorism inside Pakistan.

By June 29, 2009, the operation commencing from different directions was linked up at critical Junctions and with securing of Biha valley in the North and Shamozai in the West, main areas occupied by terrorists have been cleared. Their command structure has been totally dismantled, their training centers discovered and destroyed, their recruits either killed or driven away/ran away, their ammunition dumps destroyed and their Headquarters at Peochar, Chaprial, Matta, Khawazakhela, Mingora, Kabal, Banai Baba Ziarat, Sakhra Valley, Saidu Sharif and Biha have been destroyed. Security forces operating in Swat successfully established link up at Khel Kandao, while operating at Bunir and are consolidating their positions in areas around Dangram, Kukaraiand Jambil. Security forces secured area around Khazana, Zarra Khela and Garai and are consolidating clearanceand search from Shalkosar towards Jukhtai and Balasur towards Shah Dheri. Secured areas of Kabbal, Dhadara, Akhun Khalle, Rangeela, and Zarra Khela. Security forces commenced (Haq, 2009).

The operation made significant success within days and weeks. By 30 June 2009, security forces have claimed of cleaning up of the Swat Valley, Malakand, Mingora, and Char bagh by hunting down as many as 1635 terrorists, and arrest round about 254 terrorists, elimination of their camps, hideouts. The operation Rah-e-Rast has successfully dismantled the terrorist network in the Malakand Division within 60 days (Haq, 2009).

Briefing reporters about the progress of Operation Rah-e-Rast, military spokesman Major General Athar Abbas said, the level of foreign support that the TTP terrorists are getting from Afghanistan. Large caches of weapons of US and INDIAN origin have been found as the security forces completely secure control of Mingora city, destroying various training centers of terrorists and killing important militant commanders, the military said. The Americans have their excuses in order. Earlier this year it was exposed that over 200,000 US weapons including assault (physical attack) rifles and grenade launchers are 'missing' from the US army's record in Afghanistan. The US army is unable to provide serial numbers for a large number of the missing weapons and no records have been maintained for the location or disposition for the rest.

The Government of Pakistan and the international community need to know as to how such deadly weapons and funds were being made available to militants and terrorists. An international commission should be formed to make an inquiry into this highly dangerous situation in order to prevent from any such unpleasant possibility in the future (Haq, 2009).

\section{Conclusion}

Military operation has positive and negative impact on the people but mostly it has negative impact on society. While 
terrorism destroyed, good social values of the society. Because of not proper check of government rules and regulation in Provincially Administered Tribal Area (PATA), the illegal activities changed the behavior of the public of Malakand Division toward extremism. While the proper checked check of government brings awareness regarding positive activities, education, peace and social development in the society. But without improper check of government towards illegal activities like extremism bring negative change in the behavior of people.

In Malakand division where the literacy is low, people strong belief on religion, strict culture norms therefore it was easy for terrorists that they miss interpreted the religion towards terrorism. During research it is examined that the people of different areas has different perceptions about military operation and extremism in the region.

During military operation and militancy the people of Malakand division denied every fundamental right to life, education, movement, and freedom of expression. Women's access to education had suffered greatly in Taliban controlled-areas, as most of the schools bombed by the militants.

Through research also the implications of military operation has been investigated and discussed. The military operation affect the million of innocent people, millions of people suffered and got physical, economical, psychological and educational disabilities. According to research a lot of people face damages in the form of health, death casualties, injuries, disabilities, live stock, agriculture or all kind of damages like house, land, business etc. Because of operation common people more suffered then militants. During military operation infrastructure in the targeted area damaged due to terrorism and military operation. In Malakand division a large number of property and construction was also affected due to militancy and military operation. Besides the trouble maker have caused huge damages to public property and a large number of schools, bridges and hospitals which have deprived innocent children from education and people from health and communication facilities.

During research it is examined that only military operation is not the only way for conflict resolution. Most of the scholars give preference to conflict resolution through peace deal and mediation. Because by military operation the conflict or clash between two parties silent for present time but it is not better for long term. Throughout research we can see many damages and destruction to resolve conflict which is not proper solution and mostly fail strategy. And still there is terrorism issues in Malakand division aand also many other part of the country.

In Pakistan and Malakand civil war also first both parties were not agreeing to solve conflict through peace agreement. But when they sat for peace agreement to solve conflict then for some time the government backed out and after some time militants backed from the agreement. Pakistan government also did many peace deals with the militant groups in Wana Waziristan, FATA like Shakai agreement with Taliban leader Nek Muhammad, Sararogha Peace Deal with Mehsud dominated areas of South Waziristan, and PATA areas in Malakand Division they also did many peace deals with non-state actors like SWAT agreement the peace deal in Swat was struck on April 20, 2008 between the Awami National Party-led provincial government and followers of the Tehrik-e-Nifaz Shariat Muhammadi (TNSM) led by Sufi Muhammad. But those peace deals did not reach to a fruitful end due to lack of interest from either part of the groups.

\section{References}

Alam, A. M. ( 2013,September 6). http://www.slideshare.net/fatanews/fata-media-regulation-intermedia-2011-november.

Abid, A. L. and Khan, N. I. (2010). The Rise of Tehreek - e - Nifaz - e - Shariat - e- Mohammadi in Malakand Division, NWFP: A Case Study of the Process of "State Inversion". Islamabad: Pakistan Vision.

Aziz, K. and Helge, L. (2010). "Main Causes of the Rise of Militancy." Norwegian Institute of International Affairs.

Aziz, K. (2010). SWAT: The Main Causes of the Breakdown of Governance and Rise of Militancy. Peshawar: Regional Institute of Policy Research and Training.

Baylis, J. and others. (2008). Globalization of World Politics An Introduction to International Relations. London: Oxford.

Bari, F. (2010). Gendered Perceptions and Impact of Terrorism / Talibanization in Pakistan. NGO Report, Islamabad: Heiurich Boll Stiftung Pakistan

BBC. (2007, December 8). Pakistan hunting Swat militants. http://news.bbc.co.uk/2/hi/south_asia/7134089.stm (accessed September 5, 2013).

Brian, J. (2013, September 03). Retrieved from http://www.jewishvirtuallibrary.org/jsource/Terrorism/terrordef.html

Butt, U.\& Elahi, N. (2011). Pakistan's Quagmire : Security, Strategy, and the Future of the Islamic-Nuclear Nation. London: Continuum International Publication. Daily Times, (Islamabad) June 15, 2009

Din, N. U. (2010). Internal Displacement in Pakistan:Contemporary Challenges. Lahore: Human Rights Commission of Pakistan.

Erika, R. (2010). Swatting at files: Pakistan's use of counterinsurgency. Master of Arts in Security Studies Thesis, Washington, DC: Faculty of the Graduate School of Foreign Service of Georgetown University.

Fair, C. C, and G. J. S. (2010). "Pakistan's War Within." Survival: Global Politics and Strategy, 161-188. 
Glantz, C. D. (1991). Soviet Military Operational Art: In Pursuit of Deep Battle. Abingdon: Frank cass and company limitted.

Haq, Dr. N.ul. and Zahara, N. (2009). Malakand Post-operation Rehabilitation and Reconstruction. Islamabad: Islamabad Policy Research Institute http://archives.dawn.com/archives/26963.http://www.telegraph.co.uk/news/worldnews/asia/Pakistan/5779916/ Pakistani-president-Asif-Zardari-admits-creating-terrorist-groups.html.

Khan, N. I. (2010). "Tehreek-i-Nifaz-i-Shariat-i-Muhammadi in Malakand Division (Khyber Pakhtunkhwa): A Case Study of the Process of "State Inversion"." Pakistan Journal of History and Culture Vol.XXXI, no. 1, 131-158.

Joshi, M. (1996). "On the Razor's Edge: The Libration Tigers of Tamil Eelam." Studies in Conflict and terorism, 19-42.

Kakar, A. H. (15 November 2009). Dawn. Same militants, different aims. Retrived From http://archives.dawn.com/archives/27309 (accessed September 7, 2013)

Khattak, D. K. (2010). "The Battle for Pakistan Militancy and Conflict in the Swat Valley." New America Foundation, 8-10.

Laqueur, W. (2013, September 03). Retrieved from http://www.laqueur.net/index2.php?r=2\&id=71

Lewis, M. \& Jacqueline, S. (1999). "Kommemoratinc The Ku Klux Klan." The Sociological Quarterly (University of California Press).

Mayo, A. (08 June 2011). Daily out look Afghanistan..Rise of Malakand Taliban. Retrived From http://outlookafghanistan.net/topics. php?post_id=828 (accessed September 5, 2013)

O’Neil, P. H. (2007). Essentials of Comparative Politics. New York: W. W. Norton \& Company.

Rehman, H. u. (2011). Rising Trends of Terrorism:Causes, Dynamics and Remedies (A case study of Pakistan). The Dilogue, $409-430$.

Rana, M. A. (2009). Taliban Insurgency in Pakistan: A Counterinsurgency Perspective. Pakistan Institute for Peace Studies, 9-31.

Razzaq, S. (2010, Feb 19). Articlesbase. Importance of Media in Pakistan towards Change. Retrieved from http://www.articlesbase.com/ culture-articles/importance-of-media-in-pakistan-towards-change-1879575.html (accessed September 6, 2013).

UNICEF. (2009, July 3). Children and women displaced by conflict in Pakistan need urgent and ongoing support. Retrieved from http://www.unicef.org/media/media_50164.html (accessed September 6, 2013).

Zalman, A. (2013, September 07). Retrieved from http://terrorism.about.com/od/groupsleader1/p/Sicarii.htm

Zaheerul H. Col. Retrieved from http://pkpolitics.com/discuss/topic/victims-of-detainees-terrorism-need-justice-by-zaheerul-hassan (accessed September 4, 2013).

(2013, September 03). Retrieved from http://terrorism.about.com/od/whatisterroris1/What_is_Terrorism_and_Who_Defines_It.htm

(2013, September 03). Retrieved from http://www.infoplease.com/encyclopedia/people/brown-john-american-abolitionist.html

(2013, September 04). Retrieved from http://www.americanussr.com/american-ussr-john-brown.htm

(2013, September 04). Retrieved from http://www.siasat.com/english/news/hindu-terrorists-wanted-kill-atleast-5000-indian-muslims also 